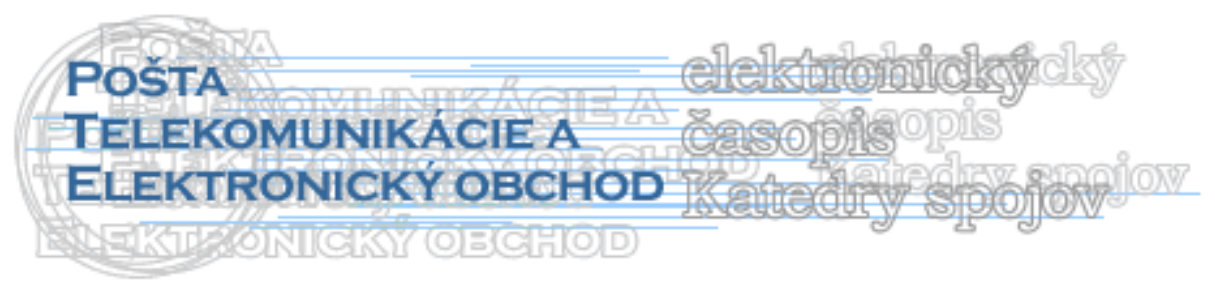

\title{
ZNALOSTI PREDSTAVUJÚ MOC
}

\author{
Milan Kubiček*
}

Úvod

To že znalosti predstavujú moc nám dáva za pravdu aj obhliadnutie sa do histórie. Na čom myslíte, že stála autorita autority v dvadsiatom a skorších storočiach? Samozrejme že to boli znalosti. Avšak dnes je táto autorita oslabená, pretože už nemajú monopol na vedomosti a znalosti. Internet a s ním d'alšie nové technológie sa rozšírili rýchlejšie ako vírus eboly, a každý tak dnes t’ukne niekol'kokrát do klávesnice a má, čo potreboval.

\section{Znalostný manažment}

Znalostný manažment môže mat' viacero podôb, aj preto je t'ažko definovatel'ný. V najjednoduchšom variante ide napríklad o zoznam zákazníckych kontaktov prístupný cez vnútrofiremnú počítačovú siet'. Zvyčajne tento pojem označuje zhromažd’ovanie, uskladňovanie a sprístupnenie sofistikovaných, t’ažko získaných a bežne nedostupných poznatkov, ktoré pomáhajú podniku fungovat' efektívnejšie. Ide napríklad o informácie o určitom geografickom trhu, výrobnom postupe či vedomosti získané pri projektoch. Osobitne cenné sú skúsenosti z praxe. Vd’aka nim sa informácie, ktoré často pripomínajú technické manuály, menia na užitočné know-how. [2]

\section{Podstata znalostí}

Znalosti sú väčšinou viazané k nejakému človeku alebo skupine l'udí. Všeobecne možno znalosti alebo ich časti charakterizovat' podl'a toho do akej miery sme schopný ich formulovat'. Na jednej strane sú jasne formulované znalosti, ktoré sa nazývajú explicitné a môžeme si ich napríklad predstavit' ako jasne definované pravidlá, ktoré sa dajú prenášat'. Na druhej strane sú skryté znalosti (tacitné) ktoré sa nedajú formulovat' alebo prenášat', alebo iba vel'mi t’ažko. Príkladom skrytej znalosti je intuícia a skúsenost', ktorú človek má a vie čo je treba v danej situácií urobit' - vykonat'. Lepšie by sa to dalo demonštrovat' na nasledujúcom príklade. Odborník na diagnostiku röntgenov vám síce pri nejasnom prípade povie, čo to je, ale pokial' sa ho opýtate ako k tomu dospel, tak to väčšinou nie je schopný formulovat'. Jednoducho to tak cíti, teda používa svoju intuíciu. Preto sa tejto znalosti hovorí skrytá, lebo je skrytá niekde vo vnútri nás a my ju nedokážeme formulovat', ale sme schopný ju použit'. Skrytú znalost' prenesieme len tak, že si ju daný človek vytvorí sám. V prípade lekárašpecialistu to znamená zaučenie a vedenie nového lekára. Ked' teda chceme preniest' nejakú skrytú znalost', mali by sme sa snažit' namiesto odovzdávania znalostí vytvárat' situácie, v ktorých si človek vytvára dané znalosti sám. Môžeme teda skryté znalosti chápat' ako znalosti, ktoré vo svojej podstate nie sú prenositel'né. Lekár špecialista nie je schopný povedat', ako funguje jeho intuícia. Čo sa týka vytvárania znalostí, ide o proces, kedy sa

\footnotetext{
* Ing. Milan Kubiček, Žilinská univerzita v Žiline, Fakulta prevádzky a ekonomiky dopravy a spojov, Katedra spojov, Univerzitná 1, 01026 Žilina, tel.: 041/513 3145, e-mail:

Milan.Kubicek@fpedas.uniza.sk,
} 
človek učí či už v škole, alebo pri nejakej činnosti alebo z vlastných chýb. Znalosti sú vytvárané hlavne pomocou zrovnávania rôznych situácií, hl'adania súvislostí, spojovaním vzt'ahov. Človek prežíva nejakú situáciu a pri nej si vytvára znalosti. Reálne situácie sú také, kedy si človek niečo skúša, vykonáva nejakú činnost'. Druhou možnost'ou je, že sa človek učí virtuálne, teda že danú situáciu neprežíva v realite, ale že si vytvára iba jej predstavu. Napríklad si predstaví ako by riešil konkrétnu situáciu. Vierohodnost' virtuálnej situácie a jej prežitie potom môže využit' pri riešení konkrétnej situácie. Vierohodnost' virtuálnej situácie a jej prežitie potom môže využit' pri vytváraní znalosti, teda poučenia z danej situácie. Lekár špecialista pomáha novému lekárovi pri získavaní znalostí tím, že mu hovorí čo je na jednotlivých snímkach. Základnými spôsobmi zdiel'ania znalostí sú rozprávanie príbehov, vytváranie komunít a učňovstvo. Všetky majú spoločné, že vytvárajú situácie. Dobrým spôsobom virtuálneho učenia sú príbehy. V príbehu poslucháč prežíva podobnú situáciu ako rozprávač. Získava teda podobné znalosti. [1]

\section{Znalostná organizácia}

Organizácia v ktorej je využívané úspešné riadenie znalostí, tzn. môžeme ju nazvat' znalostnou organizáciou, je možné identifikovat' podl'a týchto znakov:

- všetok znalostný potenciál organizácie je optimálne využívaný s tým, že najlepšie znalosti sú dostupné v každom mieste a čase, kde sú treba,

- trh znalostí v organizácii, s ich tvorcami a užívatel'mi funguje optimálne,

- kl’účové znalosti sú úspešne kapitalizované vo forme procesov, štruktúr, návrhov a patentov,

- individuálne poznatky, úspešné aj neúspešné sú menené na znalosti a sú sprístupňované všetkým pracovníkom ktorí ich využijú,

- V organizácií je implementovaný fungujúci systém školení a zoznamovania sa s najlepšími praktikami,

- všetky riziká vyplývajúce z kl’účových znalostí sú v predstihu odhal'ované,

- $\quad$ stratégia organizácie je v súlade s politikou riadenia znalostí. [6]

\section{Stratégia organizácie v znalostnej ekonomike}

Významné zmeny vplyvom globálnej znalostnej ekonomiky sa začali prejavovat' ku koncu 20. storočia, čo si vyžiadalo aj nový prístup k tvorbe stratégie organizácie v podmienkach znalostnej ekonomiky. Výsledok výskumu o strategickom plánovaní, publikovanom začiatkom roku 2006 v prestížnom časopise Harvard Business Review priniesol vel’mi zaujímavý výsledok: strategické plánovanie je prekážkou strategických rozhodnutí, pretože nie je dostatočne pružné, rýchle. Spravidla sa strategický plán prijíma na 1 až 3 roky, čo je v dnešnej rýchlej dobe pri vysokej dynamike zmien okolia neefektívne. Mnohé osvietené organizácie prestali vytvárat' strategické plány a nahradili ich strategickými rozhodnutiami, ktoré promptne reagujú na príležitosti, ktoré sa zist’ujú neustálym vyhodnocovaním externého prostredia. Výstupom nie je strategický plán, ale súbor konkrétnych strategických rozhodnutí, ktoré sa pretransformujú do podnikatel'ských plánov. 


\section{Manažment znalostí v podnikatel'skej sfére}

Základom organizácie sú znalosti. Flexibilita organizácie je závislá na znalostiach, nie na informáciách.

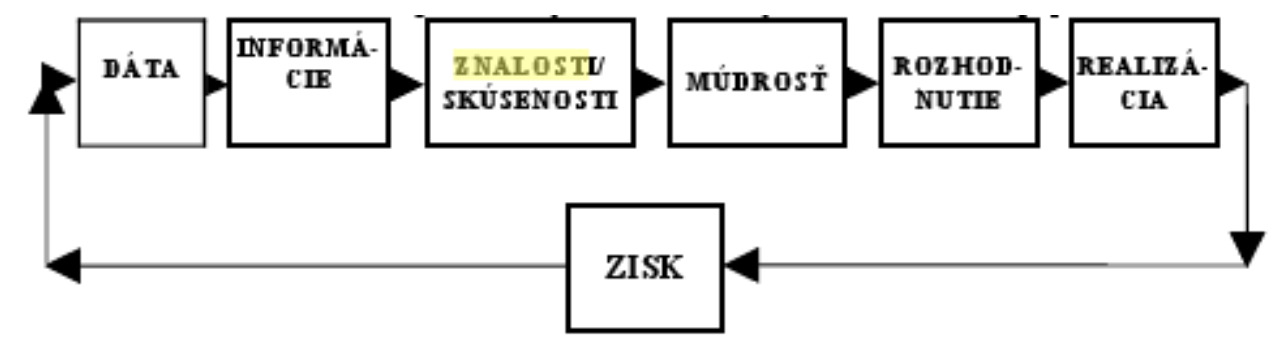

Obr. 1: Hodnotový ret’azec informačného procesu [7]

Znalosti, ktorým zákaznícky orientovaná organizácia disponuje, musia predstihnút' znalosti konkurentov i zákazníkov. Teda nielen reagovat' na objednávky, ale aktívne vytvárat' dopyt tým, že ponúka produkty, o ktorých existencii zákazníci nevedia, pretože sú produktmi vytvorenými na základe nových znalostí. Tým si organizácia aktívne vytvára svoju budúcnost' a predstih pred ostatnými organizáciami. Efektívne pracovat' s informáciami v organizácií, teda mat' znalosti, ako ich použit', neznamená, že ich musí byt' obrovské množstvo. Dôležité je vediet', ako získat' z informácií a zo znalostí, ktoré sú roztrúsené po firme konkurenčnú výhodu, čo vôbec nie je jednoduché. Jednotlivec svoje znalosti môže využívat' vždy, lebo ich má stále k dispozícii. No pre firmu, so stovkami či tisíckami zamestnancov to už problém je. L'ud'om nemožno prikazovat' zdiel'at' znalosti, ale môžeme riadit' prostredie, v ktorom sa znalosti môžu vytvárat', objavovat', zachytávat', zdiel'at', extrahovat', overovat', odovzdávat', prijímat', upravovat' a aplikovat'. A to je úlohou firemnej kultúry, ktorá bariéry zdiel'ania maximálne eliminuje, aby znalosti vol’ne prúdili a informácie boli zmysluplne využívané pri napíňaní stratégie. Dáta a informácie musia byt' verifikované a dôveryhodné a byt' vložené do kontextu. [7]

\section{Záver}

Úspešné zvládnutie zvyšujúcej sa konkurencie je jedným z klúčových faktorov prežitia podniku. Na to, aby dokázal podnik prežit' a držal krok zo svojou konkurenciou dnes už nestačí využívanie existujúcich zdrojov (l'udia, financie, suroviny, energie). Treba sa zamerat' na znalosti a duševnú prácu. Znalosti sú kl'účovým faktorom úspechu a hlavným zdrojom konkurenčnej výhody. Táto ekonomická éra ktorej hnacou silou je globalizácia trhu a konkurencia jednoznačne demonštruje, že kdo má znalosti má moc.

\section{Literatúra}

[1] Procházka, O.: Přenositelnost skrytých znalostí, 7. ročník interdisciplinárnej konferencie Znalosti 2008,

[2] http://podnikanie.etrend.sk

[3] ŠTOFKOVÁ, J. a kol.: Manažment podniku, vydavatel'stvo EDIS, 2008, ISBN 9788070-713-2

[4] BRABECK, R., ŠTOFKOVÁ, K.: Strategisches Management im postindustriellen Zeitalter = Wissensmanagement durch Information und Komunikation. In: Pošta, telekomunikácie a elektronický obchod III/2007, Žilinská univerzita v Žiline. ISSN 1336-8281 
[5] ŠTOFKOVÁ, J., ŠTOFKOVÁ, K.: Využitie metódy BSC v riadení podniku. In: Diagnostika podniku, controlling a logistika IV. medzinárodná vedecká konferencia. Žilinská univerzita, 2008. ISBN 978-80-8070-819-1

[6] http://businessworld.cz/

[7] DIAČIKOVÁ, A.: Strategické rozhodovanie a riadenie znalostí v reálnej firemnej praxi, INFORUM 2007: 13 konference o profesionálních informačních zdrojích

\section{Grantová podpora}

Príspevok je publikovaný v rámci projektu VEGA 2009-2011 „Metódy a techniky strategického manažmentu ako nástroj zvyšovania efektívnosti podnilčı 1/0757/09, Žilinská univerzita v Žiline 